\title{
SEÇÃO LIVRE
}

\section{Entrevista inédita com Jean-Jacques Courtine sobre seu percurso científico, sobre as noções de "discurso" e "corpo" como objeto de estudo.}

Entrevista realizada por Silvia Nugara, doutoranda de Ciências da Linguagem (Università degli Studi di Brescia, co-tutela Paris III-Sorbonne Nouvelle).

Tradução: Carolina Fernandes ${ }^{1}$

Revisão técnica: Maria Cristina Leandro Ferreira ${ }^{2}$

Nascido em 1945, Jean Jacques Courtine foi testemunha e ator do desenvolvimento da análise do discurso na França, em torno da figura e dos trabalhos de Michel Pêcheux. Ele contribuiu para essa teoria articulando a análise das construções sintáticas a uma visão histórica capaz de interpretar os fatos de língua (e da fala) como portadora de uma "memória" social e "ideológica". Linguista de formação, mas historiador por vocação - "eu li muito Foucault", diz ele - Courtine seguiu um caminho singular que o levou até os Estados Unidos onde permaneceu por quinze anos (1988-2003). Durante esse período, seu ponto de observação mudou, assim como os instrumentos teóricos utilizados em suas investigações. Afastando-se do "discurso" sem totalmente o abandonar, Courtine se interessou cada vez mais pelo "corpo" e escolheu inclinar-se pelo viés de um olhar, onde se misturam história, cultura e antropologia. Hoje ele é professor de antropologia cultural na Université de la Sorbonne Nouvelle - Paris III.

\section{Foi durante sua tese de $3^{\circ}$ ciclo que você encontrou Michel Pêcheux, não foi?}

Eu fiz minha tese ${ }^{3}$ na Universidade de Nanterre com Michel Arrivé. Jean Dubois foi o presidente de minha banca, mas eu encontrei Michel Pêcheux em Grenoble, num laboratório de tratamento automático das línguas. Pêcheux, devido ao seu interesse pela informática aliado à construção da análise automática do discurso (AAD 69), tinha um vínculo com esse laboratório e foi assim que eu o conheci, muito cedo, em 1971 ou 1972. Depois, em 1973, participei como assistente de linguística e pesquisador neste laboratório, o laboratório do CNRS (TALA: Tratamento Automático das línguas e Aplicações). Quando decidi fazer uma tese, eu procurei um orientador e, naquela época, não havia muitos lugares onde se podia fazer uma tese em análise do discurso: o único era Nanterre, graças a Dubois, que tinha lançado a operação "análise do discurso" 4 alguns anos antes, e por causa também do fato de Michel Arrivé, que foi meu orientador de tese, ter sido muito acolhedor. Dubois favorecia a $\mathrm{AD}$ por razões que eram provavelmente políticas - ele era marxista, reconhecia

Doutoranda do Programa de Pós-Graduação em Letras/UFRGS, na linha de pesquisa Análises Textuais e discursivas.

Professora do Instituto de Letras - UFRGS.

Jean-Jacques Courtine. Quelques problèmes théoriques et méthodologiques en analyse du discours, à propos du discours communiste adressé aux chrétiens. Langages, v. 15, n. 62, p. 9-128. juin. 1981 (Trad.bras. Análise do discurso político: o discurso comunista endereçado aos cristãos. São Carlos, SP, EDUFSCar, 2009).

Doravante: AD 
a importância da história - e também linguísticas, porque foi ele quem tinha traduzido Harris na França, e então desejava que a linguística incluísse essas questões de discurso. Finalmente, é sob o patrocínio de Dubois, com a cumplicidade de Michel Arrivé, e num diálogo constante com Pêcheux que minha tese foi realizada.

\section{Você poderia reconstruir o momento histórico e o meio científico no qual você trabalhava na época?}

Este é um ponto importante e é o mais esquecido nas reconstruções fantasmagóricas da análise do discurso que se fabricam a torto e a direito. É preciso jamais esquecer a relação inicial de tudo isso com a política. Os fundadores da $\mathrm{AD}$ eram gente de esquerda, marxistas além do mais, militantes comunistas na maioria, não é possível omitir isso. Era o caso de Pêcheux e de todos aqueles que lhe eram próximos, que se ocupavam ou não da análise do discurso - Françoise Gadet, Paul Henry, Michel Plon, Elizabeth Roudinesco, eu mesmo, com algumas exceções - aqueles que vinham com interesse pelo discurso como objeto, com preocupações mais exclusivamente lingüísticas. Eu penso, por exemplo, em Jean-Marie Marandin. Mas o lado político dessa história pesou muito no seu destino.

O entorno imediato da análise do discurso era bem este. Com Dubois por padrinho, havia toda uma corte de militantes comunistas: os historiadores preocupados com a linguística e os linguistas preocupados com a história - Régine Robin, Jacques Guilhaumou, Denise Maldidier - e assim o grupo de Rouen reunido em torno de JeanBaptiste Marcellesi, Gardin, Guespin etc., que Pêcheux e eu mesmo considerávamos comunistas ortodoxos - e, digamos a palavra, "stalinistas" - com os quais nós estávamos batendo de frente constantemente. Tinha-se, às vezes, a impressão de que era verdadeiramente isso a luta principal, a $\mathrm{AD}$ se banhava no marxismo e nas controvérsias existentes no interior do mesmo: Althusser de um lado, o partido comunista francês e sua tendência de outro... Eu creio que não é possível esquecer isso, porque, desde que foi apagada das ficções históricas que dão conta da gênese da $\mathrm{AD}$, essa questão se tornou $\mathrm{o}$ "cadáver no armário" da análise do discurso; e eu peso minhas palavras, porque se eu digo "cadáver", eu penso de imediato, lamentavelmente, em Pêcheux, maneira de dizer que a política é o pêché ${ }^{5}$ - ou o Pêcheux, quem sabe? - original da AD.

Depois, no que me concerne, eu trabalhei sobre o discurso comunista endereçado aos cristãos enquanto se estava em pleno período da União da esquerda, a qual foi rompida pelos comunistas em 1977. A União da esquerda seguia essa "política da mão estendida" do Partido Comunista Francês a todas as classes populares e correntes políticas democráticas, de maneira a formar uma frente de esquerda comum, como a Frente Popular tinha feito em sua época. O Partido Comunista, nas suas negociações históricas com ele mesmo, entre políticos sectários ou apoiadores das bases operárias ou de abertura, como se diria agora, diante de toda uma série de elementos que lhe eram heterogêneos, escolheu essa política da União da esquerda. Mas, em um dado momento, o PCF (Partido Comunista Francês) se deu conta de que Mitterrand, em seu fim político, estava virando tudo do avesso para o seu proveito. Então, em 1977, os comunistas se voltaram novamente sobre essa base operária e sectarista, que era sua base tradicional desde os anos 20 , e em conseqüência, a União da esquerda foi rompida.

E assim essa política de união foi liquidada do dia para a noite, e foi nesse contexto que eu desenvolvi minha tese sobre o discurso comunista endereçado aos cristãos. Ou seja,

\footnotetext{
$5 \quad$ Nota de tradução: a palavra pêché, indicando o nome de Pêcheux, fundador da $\mathrm{AD}$, faz homofonia com a palavra péché, cuja tradução é pecado.
} 
eu escrevi esse texto entre 1977 e 1979, praticamente "no calor da hora", para, sem dúvida, fazer progredir a AD sobre o plano da ciência, mas igualmente - e sobretudo - para tentar compreender o que tinha sido essa tendência política nos dispositivos discursivos que a exprimiam. Eu fiz parte, como Pêcheux, daqueles que, no momento da ruptura da União da esquerda, recusaram essa nova tendência e se expressaram nos jornais, no Le Monde em particular, assinando publicamente petições. Isso não parece nada hoje, mas naquela época não era nada mesmo, quando se era militante comunista. Então tentamos lutar dentro do partido contra o partido, mas isso não durou muito tempo, porque, quando damos cabeçadas em um muro que não se move, se não formos completamente masoquistas, um belo dia paramos. Minha tese foi então escrita nesse contexto. Havia mais que um simples interesse pelo discurso político. O que me interessava era mostrar, por meio das próprias estruturas do discurso, que a política da mão estendida era um pseudo-diálogo que não correspondia quase nada ao desejo de abertura fixado. De onde igualmente tirei meu interesse pela questão da memória: eu tentava antes mostrar que essa tendência política obedecia a uma memória do discurso, e que essa última determinava demasiadamente esse corpus, que era originado apenas a partir de repetições, apagamentos, esquecimentos, redundâncias, lapsos, lacunas dessa memória pela qual as coisas podiam ser compreendidas. Assim, a história da AD na França, particularmente no seu começo, é igualmente uma história política.

Diz-se, frequentemente, que a AD é um campo de estudo multidisciplinar ou até mesmo transdisciplinar. A partir de qual abordagem disciplinar você trabalhava na época?

É complicado, aliás, a resposta anterior mostrou bem isso. A $\mathrm{AD}$, nos projetos dos quais eu participava, analisava em minúcias, debulhava o texto demasiadamente. Havia pessoas nela cujo futuro era se tornarem linguistas e de continuar a sê-lo. Eu penso, por exemplo, em Jean-Marie Marandin, que deu uma pequena volta e depois voltou à linguística formal como se nada tivesse acontecido. Este não era meu caso. Eu estava antes de tudo preocupado com questões históricas e políticas e, secundariamente, com questões linguísticas. Quando fazíamos reuniões de pesquisa com Pêcheux, havia uma piada corrente que consistia em dizer que eu adormecia logo que se começava a falar em sintaxe. Eu devo reconhecer que isso não era inteiramente falso. Mas eu mesmo forcei minha natureza, porque se nós proclamávamos com Pêcheux que existia um "real da língua", então era preciso efetivamente passar por uma análise formal. Outra coisa que estava em jogo era mostrar que havia a possibilidade de construir temas do discurso fora da delimitação $a$ priori da palavra, como o fazia Tournier e sua equipe de lexicógrafos da Escola Normal Superior (ENS) de Saint Cloud, coisa que, aliás, as pessoas continuam mais ou menos imperturbavelmente fazendo em nossos dias. Minha ideia era que no próprio discurso se podia encontrar critérios formais, de maneira a delimitar os termos dos quais o próprio discurso se apoderava quando era enunciado, termos dos quais ele fazia temas que se opunham a outros. Tratava-se mais do que contar palavras, o que, para mim, não tem interesse algum, não tinha outrora, e tampouco hoje. Quando vemos o que está em jogo atualmente na representação política, o papel da imagem, a complexidade das mixagens de imagens e discursos, quando vemos a fluidez e a instantaneidade dos discursos e quando vemos o que fazem dele na lexicometria, eu me pergunto simplesmente o que isso permitiu compreender do processo político.

Eu retorno à questão da multidisciplinaridade da $\mathrm{AD}$. Dentre as pessoas que estavam na $\mathrm{AD}$, havia Pêcheux que era filósofo, com um forte interesse pelas máquinas, 
pelos dispositivos e os aparelhos ${ }^{6}$. Eu estava a um passo de me tornar historiador, mas, na época, eu não sabia disso verdadeiramente. Minha relação com a história, eu a percebi nesse trabalho de tese, quando eu compreendi, a princípio, que precisava absolutamente tentar delimitar historicamente o corpus e o que o determinava e, em segundo lugar, compreendi igualmente que havia uma história de discursos, uma memória atuando ali dentro, e que se tratava de alguma coisa de essencial. Logo, havia evidentemente uma forma de interdisciplinaridade, mas não a chamávamos assim, porque havia o marxismo atrás disso tudo, que era a referência última. Desse modo, havia uma espécie de tríplice aliança entre o marxismo althusseriano, a linguística e a psicanálise lacaniana. Se havia uma interdisciplinaridade, era esta: a ideia de Pêcheux era de que havia algo que se chamava "o real da língua" de um lado e o "real da história" do outro lado...

\section{Então o extralinguageiro era compreendido inteiramente no aparelho teórico da AD...}

Perfeitamente. Pelo menos era compreendido teoricamente, uma vez que eu percebi um pouco mais tarde que a relação com a história era um encantamento, um slogan e que, quando a gente se põe a fazer verdadeiramente história, aí são outros quinhentos. Ou seja, quando nós nos propomos a trabalhar de fato com corpus que tem uma complexidade histórica real, isso não é como tomar o discurso endereçado aos cristãos entre 1936 e 1976 em um corpus onde há apenas discurso comunista numa tradição discursiva homogênea, mesmo se nele nos incluímos, pois eu trabalhei assim, com discursos que vinham da política social da Igreja... Quando se trabalha de fato sobre materiais heterogêneos de longa duração, isso é um outro caso. É nesse momento que fazemos história, e é nesse mesmo momento que se coloca a questão de saber se nós podemos casar a história com uma perspectiva linguística qualquer. Na época em que eu trabalhava com Pêcheux, não se tinha esse questionamento: a história era constantemente utilizada como uma fórmula mágica, mas o trabalho histórico era pouco praticado. Havia também historiadores que trabalhavam sobre o discurso: Régine Robin, em particular, e Jacques Guilhaumou, que percorria essa via. Mas, sem querer tirar a qualidade de seu trabalho, quando se vê as coisas na perspectiva do ponto de onde nós estamos hoje, eu receio dizer que isso foi um fracasso. $\mathrm{Na}$ história, a $\mathrm{AD}$ não produziu nenhum efeito. Eu não conheço um historiador hoje que trabalhe dessa maneira que se trabalhava na $\mathrm{AD}$.

\section{Qual era a definição que você dava para a noção de discurso na época?}

É preciso lembrar que a cada vez que definíamos essa noção era dentro do universo intelectual que eu acabo de esboçar. Ou seja, a definição de discurso partia da de ideologia, da dominação ideológica e das contradições no interior das formações sociais. Havia, desse modo, uma formação ideológica que se materializava nas formações discursivas, e é a partir disso que a questão do discurso intervinha como a materialidade própria dessas formações discursivas, elas mesmas tecidas pela materialidade linguageira. Então, você vê que se partia de alguma coisa que era da ordem da ideologia e da história para chegar a coisas que não eram de nenhuma dessas ordens.

6 Michel Pêcheux. L'analyse automatique du discours. Paris, Dunod, 1969. (Trad. bras. Análise automática do discurso in: GADET, F. \& HAK, T. (orgs). Por uma análise automática do discurso - Uma introdução à obra de Michel Pêcheux.Campinas, Ed. da Unicamp, 1990). 
Se o marxismo, ou para ser mais precisa, a leitura que Althusser fez de Marx, era o fundo conceitual e militante sobre o qual se desenvolviam as tentativas teóricas da AD, o que há hoje? Por qual combate/abordagem, filosofia/visão lhe parece que o quadro teórico e militante foi substituído pela AD?

Havia então uma direção, um projeto, uma perspectiva política, um engajamento. Hoje, parece que não há mais nada daquilo, salvo algumas ambições acadêmicas e disciplinares. Eu falo assim, sem querer fazer polêmica, mas, quando eu abro o Dicionário de Análise do Discurso ${ }^{7}$ que foi produzido não faz muito tempo, quando vejo nele as referências e os desenvolvimentos, há várias coisas que me chocam: o abandono, primeiramente, de toda a perspectiva teórica ou histórica e o retorno, em segundo lugar, a problemáticas antigas ou mais recentes - retórica, semiologia, comunicação, pragmática das quais a $\mathrm{AD}$ precisamente tentou se desfazer durante sua constituição. Há, em todos os casos, um retrocesso, uma grande confusão. Ou seja, depois dessa espécie de momento brilhante de teorização inicial, a análise do discurso se re-disciplinarizou. Ela, de certa forma, se re-territorializou: reencontrou, assim, formas antigas como a retórica ou a semiologia, e tende a se confundir com as problemáticas contemporâneas da comunicação. Se nós colocarmos lado a lado um dicionário de retórica moderna, um dicionário de comunicação, outro de semiótica e esse dicionário de $\mathrm{AD}$, nós vemos que eles se assemelham profundamente.

Como consequência, eu tenho medo que os elementos básicos da matéria conceitual que ainda sustenta a $\mathrm{AD}$ (formações discursivas, pré-construído, discurso transverso ou interdiscurso, enunciado no sentido discursivo e não no sentido linguístico do termo, memória discursiva etc.), mesmo quando se apresentem travestidos, datem apenas dessa época de fundação da AD. Eu digo tudo isso sem nenhuma nostalgia, mas esse foi um momento de produção teórica intensa, e é o que promoveu a $\mathrm{AD}$ como disciplina, que a fez existir, e continua a fazê-la existir intelectualmente. Tudo começou por volta de 68 Pêcheux escreveu sua tese em 1969 - e se estendeu até o começo dos anos 80. Desde então a $\mathrm{AD}$ só conheceu rearranjos, ela vive ainda em cima dessas aquisições teóricas. Da minha parte, é no começo dos anos 80 que eu compreendi que precisava me afastar da AD.

\section{Seu caminho já divergia com respeito à direção que a AD estava tomando?}

Sim, eu parti entre outros motivos por isso. Não por causa de Pêcheux, pelo qual eu tinha muito respeito e a quem eu continuei a estimar enormemente, mas ele tomava uma via que não parecia ser a minha. Eu estava já na história e ele estava fascinado pelo paradigma linguístico chomskyano, e isso me parecia que ia levá-lo para onde eu não queria ir.

Então, hoje, você critica a falta de evolução da $A D$, mas você não objeta a utilidade atual de uma noção tal qual, por exemplo, a de "formação discursiva"...

É preciso saber o que se faz. Se nós tomamos a noção de "formação discursiva" a sério, é preciso saber que isso vem de Foucault e que ela nos arrasta para o terreno da história, ao qual eu havia resistido na época em que escrevi Langages 62. O terreno da

7

Patrick Charaudeau e Dominique Maingueneau (orgs.). Dictionnaire d'analyse du discours. Paris, Seuil, 2002. (Trad. bras. Dicionário de análise do discurso. São Paulo, Contexto, 2004.) 
história supõe uma reviravolta total da problemática. Supõe-se que não se vai se divertir trabalhando, como muitos fazem, sobre quatro recortes de imprensa, três publicidades e um pouco de vulgarização científica. Eu quero dizer que se, verdadeiramente, faz-se entrar a história ali dentro, através da noção de "formação discursiva", então se está em um outro domínio.

\section{Um dos conceitos com os quais você contribuiu para o aparelho teórico da AD é o de "memória discursiva". De onde essa noção nasceu?}

Esse conceito voltou a tomar de maneira muito literal a ideia de que no discurso há sempre um "já lá" e, sendo assim, há uma saturação por uma memória discursiva de formulações enunciadas, repetidas, reproduzidas, e que há, ao mesmo tempo, deslocamentos, lacunas, apagamentos, falhas, e era isso que me interessava. Era uma noção que me tinha sido inspirada por Arqueologia do Saber ${ }^{8}$ onde não havia o termo "memória discursiva", mas havia um "domínio de memória" do discurso. O problema é que o termo "discurso", em Foucault, não pertencia ao terreno propriamente linguístico no qual a AD se situava. Para ele, esse termo só valia em relação àquilo que ele chamava de "dispositivo", a saber, um conjunto de instituições, regulamentos, leis, práticas, textos, imagens, gestos, posturas etc. que são todos atravessados por alguma forma histórica determinada que lhes dá uma certa coerência. O discurso, em Foucault, é essa forma, essa singularidade histórica e coerente, mas se pode evidentemente ver que aquilo que ele chama de "discurso" pode- se materializar em textos, mais especificamente nos corpos, nas instituições, mas também nos dispositivos arquitetônicos... Tomemos o discurso sobre a irracionalidade no século XII: trata-se, às vezes, de um conjunto de textos médicos, filosóficos, de leis e de regulamentos, mas também de prédios, de hospitais em geral, de práticas de enclausuramento, de limitações sobre corpos: é ainda tudo o que vemos, o que nos é mostrado e o que nos é escondido. É isso que ele entendia por "discurso", é a diferença última que atravessa e liga tudo isso. Estamos longe, evidentemente, do ressurgimento do termo "discurso" sobre uma problemática linguística para a qual eu me sinto um pouco culpado de ter contribuído ${ }^{9}$. Essa confusão foi repetida desde então e se solidificou numa espécie de vulgata tenaz. Eu parei de fazer $\mathrm{AD}$ para dizer "não" a tudo isso, para dizer que eu não me reconhecia mais dentro dela. Paul Veyne acaba de escrever um livro sobre Foucault ${ }^{10}$ no qual os dois primeiros capítulos esclarecem esse ponto e devem ser considerados por todos aqueles que fazem AD se referindo a Foucault. Ele diz alguma coisa como: "muitos leitores abusaram do termo 'discurso' em Foucault", o qual é um lugar de confusão e de mal-entendidos.

\section{É uma questão de polissemia, um dos principais problemas que a língua nos coloca...}

Perfeitamente, mas há ao menos duas ou três razões para esse mal-entendido. Primeiro, Foucault não se serve apenas do termo "discurso". Ele se serve também, de modo frequente e bastante semelhante, de "dispositivo", de "episteme", de "pressuposto", de "prática discursiva" e tudo isso que flutua; a não ser em Arqueologia do Saber e As

\footnotetext{
$8 \quad$ Michel Foucault. L'archéologie du savoir. Paris, Gallimard, 1969. (Trad. bras. Arqueologia do Saber. Rio de Janeiro, Forense Universitária, 1987)

9 Jean-Jacques Courtine. "Entrevista com Nilton Milanez". In: Corpo, olhar, discurso: a herança de Michel Foucault. (prelo)

10 Paul Veyne. Foucault : sa pensée, sa personne, Paris, Albin Michel, 2008. (Ainda não traduzido para o Português).
} 
palavras e as coisas $^{11}$ onde ele utilizou de maneira predominante "discurso", porque ele trabalhava com textos. Veyne disse bem em seu livro: como ele desconfiava da metafísica e queria dar um lado concreto ao seu estudo - ele desafiava as verdades gerais dos filósofos ele trabalhou a partir de regulamentos de hospitais e de asilos, e isso o situou nesse domínio de possibilidades e de materialidades discursivas.

Uma segunda razão é que, naquele tempo, havia "discurso" por toda parte e, então, ele provavelmente cedeu à conjuntura da época. Uma terceira razão é que As palavras e as coisas teve um sucesso louco e a ideia se espalhou como se de um lado houvesse as palavras e de outro as coisas. É preciso ainda acrescentar que, em um momento dado, ele se distanciou disso tudo. Quando, em 1982, no trem, entre Paris e Grenoble ${ }^{12}$, eu tive uma longa conversa com Foucault a propósito da $\mathrm{AD}$, ele foi muito polido, mas me fez compreender que, decididamente, isso não o interessava. Porém o motivo eu só compreendi mais tarde.

\section{É possível que o tivesse lido com a abordagem de um período histórico ou tudo era linguagem...}

Sim, mas isso não é simplesmente uma questão de funcionamento do tempo. Eu posso tentar responder por mim, na falta de fazer de maneira mais geral: no que me concerne, eu mudei a forma de trabalhar e a imersão em verdadeiras questões de arquivo e o trabalho histórico verdadeiro me abriram os olhos. Eu percebi que quando se trabalha com uma duração longa, dois ou três séculos, as questões "discursivas" presentes ali põem em jogo "dispositivos", no sentido de Foucault, complexos e heterogêneos. Então, descobrir neles regularidades era bem mais complicado que determinar montagens sintáticas formais em corpora de textos extremamente redundantes. $\mathrm{Na}$ análise de dispositivos de longa duração, a AD é simplesmente inoperante.

Você acredita que a ideologia pode ainda ser uma categoria pertinente para a análise do discurso político, uma vez despojada de toda "análise de classe" e definida em termos de "manipulação" que "naturaliza" um discurso culturalmente construído para o tornar consensual?

Essa é uma questão complicada, mas justa, porque os efeitos ideológicos são constantes. O fenômeno que foi chamado de "fim das ideologias" nos anos 80 era, sobretudo, o fim de um discurso, o fim do marxismo como teoria da ideologia definida como produto das contradições de classe. Esse foi o fim brutal dessas ideias - e até mesmo desses que as carregavam - mas isso não quer dizer que não haja mais ideologia. É justo buscar ideias novas para interpretar as formas de dominação de hoje, que são mais complexas. De um lado há o capitalismo global das multinacionais, que desloca as usinas e os capitais e, de outro, há o empobrecimento, a aflição das massas que se diziam outrora "trabalhadoras", por causa do fenômeno que se chama "deslocamento". Vê-se hoje uma realidade mais complexa, mas não menos cruel. Até porque temos agora a onipresença desse aparelho de informação que pontua a vida das pessoas, que passam, na França, em média três horas e meia de seu dia e, mais ou menos, doze anos de sua vida, diante da

\footnotetext{
11

Michel Foucault. Les mots et les choses. Paris, Gallimard, 1966. (Trad.bras. As palavras e as coisas: uma arqueologia das ciências humanas. São Paulo, Martins Fontes, 1966).

Jean-Jacques Courtine. Entrevista com Nilton Milanez. In: Corpo, olhar, discurso: a herança de Michel Foucault. (No prelo).
} 
televisão, fator ideológico principal. Em consequência disso, a questão dos efeitos de dominação e de subjugação culturais continua mais que nunca a se colocar.

Eu penso, por exemplo, em tudo que se passa em torno do corpo e, em particular, do corpo da mulher com o questionamento de que há leis que permitem o direito ao aborto...

Certamente, e é bem mais complicado que se fosse tratar de alguma coisa ditada pela burguesia, como a classe social. Muitas pessoas não sabem o que essas palavras querem dizer. Sabe-se que há ricos e pobres, que há excluídos, sem-documentos, infelizes, perseguidos, e que, mesmo nas classes médias, existem formas de empobrecimento e que, em oposição, há camadas extremamente ricas, reduzidas, móveis e nômades. Logo, não é mais a análise tradicional em termos de classe que pode nos ajudar a compreender o fenômeno. Mas se a $\mathrm{AD}$ quisesse ser fiel ao que foi lá em sua origem, ela deveria se preocupar com essas questões.

Você chamou atenção e criticou com efeito o que denominou de gramaticalização da $\mathrm{AD}^{13}$. Entretanto, o aspecto formal da análise era já muito presente desde Pêcheux, que se servia de instrumentos rigorosos da sintaxe para em seguida desenvolver interpretações, assim como quando você estudou os lugares da memória discursiva ${ }^{14}$. Quando é que a análise formal se transforma em vício?

Eu vou lhe contar uma história sobre isso. Eu estava, recentemente, em um congresso sobre a medicina, a literatura e as ciências da vida desde a Revolução, onde havia historiadores da cultura, psicólogos clínicos, historiadores da medicina e da psiquiatria e literatos. Havia também dois linguistas que participavam desse congresso. Eles se apossaram de Charcot $^{15}$ e de seus textos e fizeram análises enunciativas e sintáticas para mostrar que ele era um desclassificado que exibia mulheres histéricas em um teatro, nas terças-feiras, à tarde, no Salpetrière ${ }^{16}$. O problema é que havia lá especialistas em Charcot, historiadores que disseram que não permitiriam críticas de um amadorismo igual. Disseram ainda que é preciso conhecer as implicações daquilo que está em jogo em um corpus e que, se não se tem o saber histórico que permite compreender profundamente a complexidade de todo o assunto analisado, não se compreende nada de nada. Eu, que venho da linguística, disse-lhes que tinha muita empatia por historiadores porque eu tinha outrora encontrado esse problema. Mas que, se não compreendemos o que está em jogo historicamente em um corpus, fazemos inutilmente todas as análises formais que queremos, conhecemos bem uma porção de coisas sobre a diferença entre as relativas, determinativas e explicativas e isso não serve estritamente para nada. Os linguistas ficaram muito irritados: eles não concebiam que a determinação das condições de produção históricas de seu corpus, para falar como se

\footnotetext{
13 Jean-Jacques Courtine. Le discours introuvable : marxisme et linguistique (1965-1985). Histoire, Epistémologie, Langage, 1991, v. 13, n. 2, p. 153-171. (Trad.bras. O discurso inatingível: marxismo e lingüística (1965 - 1985). Trad. Heloisa Monteiro Rosário. Cadernos de Tradução do Instituto de Letras/UFRGS. Porto Alegre, n. 6, 1999, p. 5-18).

$14 \quad$ Jean-Jacques Courtine. Quelques problèmes théoriques et méthodologiques en analyse du discours, à propos du discours communiste adressé aux chrétiens. Langages, v. 15, n. 62, p. 9-128. juin. 1981 (Trad.bras. Análise do discurso político: o discurso comunista endereçado aos cristãos. São Carlos, EDUFSCar, 2009).

Jean-Martin Charcot (1825 - 1893): foi médico e cientista francês, adquiriu reconhecimento no campo da psiquiatria na segunda metade do século XIX, sendo considerado o "pai da neurologia moderna". Foi professor de Sigmund Freud.

Hospital da Salpêtrière é um hospital psiquiátrico de Paris. Originalmente construído para ser uma fábrica de pólvora no século XVII, tornou-se um depósito de mendigos, doentes mentais e criminosos insanos que eram afastados da sociedade com o intuito de se manter a ordem pública. Após a Revolução, serviu de sanatório para mulheres, onde atuava Charcot como professor.
} 
fazia na $\mathrm{AD}$, merecesse o mesmo cuidado que aquilo que eles davam à delimitação das marcas enunciativas. Eles pensavam poder interpretar os textos sem história, ou melhor ainda, legitimar, por uma análise linguística, a história "espontânea", a narração préconstruída que os havia guiado em direção à escolha desse corpus: sim, decididamente, esse médico era bem um grande manipulador, e essas mulheres, suas vítimas... A sintaxe e a enunciação dos discursos provam isso.

\section{Mas é preciso mesmo assim uma análise formal do corpus...}

Sim, se quisermos fazer AD. Se quisermos fazer história, às vezes, não sempre, às vezes de modo nenhum; isso depende do que se pesquisa. Mas essa anedota é um exemplo de "gramaticalização" da $\mathrm{AD}$, de seu afastamento das perspectivas históricas que ela quisera articular, inicialmente, à análise das sequências discursivas. É por isso que, quanto a mim, pouco a pouco, eu me afastei da AD. Porque havia dois elementos originais na AD: havia de um lado o que se chamava de "condições de produção", e é isso que precisava para compreender e analisar os determinantes históricos de um corpus, e depois havia o trabalho formal sobre o texto; e era a relação entre esses dois aspectos que fazia a AD. O que eu constatei é que a primeira parte desse trabalho foi progressivamente abandonada e que a segunda foi consideravelmente reforçada sob uma forma ou outra: fio do discurso, conectores, sintaxe... Em todo caso, eu me dei conta, só depois, que era, antes de tudo, a primeira parte da $\mathrm{AD}$ que me interessava. Nessa história cômica que eu acabo de contar, vêse o que acontece quando não se mantém o fio histórico, ou seja, ninguém pode dizer nada sobre o discurso, e a aparelhagem formal da qual nos cercamos não é uma garantia interpretativa.

A meu ver, sua visão pessoal da realidade transparece já em sua escrita. Nos seus textos, encontra-se uma preocupação com o ritmo, um gosto quase narrativo que, em último caso, transforma o raciocínio científico numa espécie de aventura. Qual relação você tem com a escrita em geral e com a escrita acadêmica em particular?

Essa é uma questão subjacente a toda minha história. É verdade que, na maneira de escrever a $\mathrm{AD}$, como fizera em minha tese, eu sentia, às vezes, o prazer de elaborar dispositivos formais, mas também uma frustração: eu tinha necessidade de contar histórias, e isso eu não podia fazer, porque o fio da escritura em AD é continuamente quebrado por exemplos, pelas referências, e logo não há uma verdadeira possibilidade de escrever. Para mim, escrever é essencial. Assim, eu me dei conta de que a sedução pelo modelo foucaultiano era, para mim, de uma parte, ligada à escrita de Foucault. Foi só a partir da História do rosto ${ }^{17}$ que eu pude escrever. Essa "felicidade do texto" eu encontrei ali como eu não a encontrara na escrita "científica", e isso então contou muito. Mais eu sinto as contradições acadêmicas, mais eu aprecio essa liberdade de escrita, é uma sorte, uma felicidade que oferece nossa profissão, mas isso foi uma liberdade bastante reivindicada. A verdade é que o estilo científico das comunicações linguísticas tornou-me completamente estrangeiro e é por isso que eu faço história, porque ali se pode escrever... histórias. Veja Foucault, Michelet ${ }^{18} \ldots$ Pode-se então contar histórias. É verdade que se trata de uma

\footnotetext{
17 Jean-Jacques Courtine e Claudine Haroche. Histoire du visage: exprimer et taire ses émotions (du XVIe siècle au XIXe siècle). Paris, Éditions Rivages, 1988. (Trad. port. História do rosto: exprimir e calar suas emoções (do século XVI ao início do século $X X)$. Teorema, Lisboa, 1988). Jules Michelet (1798 - 1874): Filósofo e historiador francês.
} 
narração que obedece a certos critérios, mas a forma narrativa está presente: é preciso encontrar os cenários que permitam explicar as coisas. Por exemplo, para a História do corpo $^{19}$ eu escrevi essa história da deformidade que vai da monstruosidade à deficiência, trata-se de uma narração que tem um fio, que tem transformações, objetos, momentos e é um grande prazer elaborá-la.

\section{Você gostaria de escrever outra coisa, um romance, por exemplo?}

Eu penso que poderia ir mais longe na narração histórica, mas me situar no terreno da ficção pura é complicado. A escrita é um lugar terrível onde entrevemos grandes possibilidades e experimentamos continuamente os limites. Em suma, eu tenho medo que os meus limites não me permitam isso. Eu penso que no domínio da história, da antropologia histórica e no domínio do ensaio eu posso escrever com certeza, mas se eu precisar soltar as amarras, abandonar uma certa relação com a documentação, com a realidade positiva, eu creio que seria tomado por uma grande inquietude.

\section{É um receio de sua solidão frente à escrita?}

Sim, porém mais ainda, eu teria a impressão de uma grande abstração, de me puxar pelos cabelos para me levantar do chão. Logo, eu tenho medo disso. Eu tenho amigos, como, por exemplo, o romancista argentino Noé Jitrik, com quem eu me correspondo, que me aconselham a escrever, mas eu resisto. Quer dizer: é uma coisa de que eu gosto muito de fazer ao traduzir. Eu tenho muito prazer em traduzir do inglês, coisa que eu faço de tempos em tempos. Por exemplo, eu traduzi recentemente um ensaio de $\mathrm{Swift}^{20}$. Há ali o prazer do apagamento, de marcar, às vezes, uma presença e uma ausência. Isso me tranquiliza. Melhor: isso me alivia.

Há uma espécie de mitologia acadêmica que circula, e que fala de você como aquele que partiu, mas, principalmente, daquele que mudou e migrou de uma disciplina para outra. Você partilha desse mito de ruptura epistemológica que lhe concerne ou de modo algum?

Há diferentes elementos. Primeiro eu nunca me senti à vontade nas disciplinas; eu não tenho o sentimento de poder me identificar, integralmente, com o núcleo central de uma disciplina, onde alguns parecem chegar. Mas isso leva a formas de nomadismo intelectual e eventualmente geográfico.

Além disso, há o fato de que o pensamento de Foucault me marcou muito, pois há em seus textos uma grande liberdade e elementos que atravessam as disciplinas. Eu acredito nisto: de que é preciso procurar o lugar onde se respira melhor. Há quem consegue respirar em uma atmosfera confinada, eu não. Eu tenho afinidades intelectuais com alguns indivíduos, mas eu jamais faço parte de redes disciplinares tais quais existem por aí. E eu

\footnotetext{
19 Alain Corbin, Jean-Jacques Courtine, Georges Vigarello (orgs.). Histoire du corps. Paris, Seuil, 2005-2006. (Trad. bras. História do Corpo. 4 ed. Petrópolis: Vozes, 2008 - 3 volumes).

20 Jonathan Swift. L'art du mensonge politique. Grenoble, Jérôme Million, [1733/1993]. (Trad. bras. A arte da mentira política - precedido pelo texto "O mentir verdadeiro" de Jean-Jacques Courtine - trad. Mônica Zoppi-Fontana e Roberto Leiser Baronas. Campinas, Pontes, 2006).
} 
me encontro bastante nas relações intelectuais e editoriais construídas por meio de afinidades, de curiosidades, como no caso do grupo com o qual trabalhei a História do corpo. Mas as bancas, as teses, as disciplinas, as comissões, os conselhos, isso não é verdadeiramente o que eu aprecio.

Uma outra parte ainda do problema é que não é simples se reconhecer dentro de uma disciplina, sentir-se pertencente a ela: quando se começou a fazer $\mathrm{AD}$, eu me dei conta de que eu tinha me tornado linguista por uma espécie de mal-entendido e, uma vez isso reconhecido, é complicado, há escolhas a fazer. Pode-se prolongar esse mal-entendido e escolher fabricar carreiras ali. Estava acima de minhas forças. E isso me levou a me deslocar, tanto no plano disciplinar quanto no plano geográfico. Eu sou reconhecido por isso à universidade americana, que me recrutou pelo que eu tinha feito e me permitiu, no meio de minha carreira, dar a volta, turn it around, como eles dizem, mudar e continuar.

\section{Há, de qualquer maneira, uma relação entre o "discurso" sobre o qual você trabalhou no início e o "olhar" sobre o qual você trabalha agora ${ }^{21}$; não seria isso por conta de uma abordagem da realidade como construção...}

$\mathrm{Na}$ época em que eu elaborava minha tese, a leitura mais profunda que eu fiz foi a de Arqueologia do Saber, e eu penso que a questão do olhar estava lá já posta. Há em Foucault essa ideia de que os discursos são também maneiras de ver, que compreendem também percepções, corpos; logo o fio que liga o corpo, olhar e discurso se tornou uma relação essencial para mim, com variações. Tudo isso se encontra já em Foucault, como o mostra Deleuze ${ }^{22}$. A partir da História da face, a questão do corpo e do olhar está evidentemente presente sob a forma de um trabalho sobre o corpo que é olhado, mas também sobre o corpo que olha. Tudo isso estava no cerne daquilo que interessava Foucault. Independente de diferentes objetos sobre os quais eu trabalhei, há neles um núcleo, um discurso que atravessa essas coisas, ao qual eu estive muito sensível.

Não havia, em sua opinião, uma possibilidade de continuar a trabalhar sobre o corpo no interior das ciências da linguagem? Eu penso, por exemplo, na eventualidade de usar uma abordagem semiológica.

Provavelmente, mas a semiologia não me atrai. Na Sorbonne, eu ministro aulas de antropologia da imagem, e eu tenho uma abordagem diferente. A semiologia como transposição de métodos e conceitos linguísticos sobre imagens não me interessa, eu não acredito nisso nem um pouco. Eu me reconheço muito mais em uma perspectiva como aquela de Carlo Ginzburg, em «Signos, traços, pistas » ${ }^{23}$, ou na problemática de Hans Belting. $^{24}$

\footnotetext{
21

O terceiro tomo de Histoire du corps foi dirigido por J-J Courtine e se intitula Les mutations du regard. Le XXe siècle. (Trad. bras. Alain Corbin, Jean-Jacques Courtine, Georges Vigarello (orgs.). História do Corpo: mutações do olhar - o século XX. 4 ed. Petrópolis, Vozes, v. 3, 2008).

22 Gilles Deleuze. Foucault. Paris, Ed. de Minuit, 1986. (Trad. bras. Foucault. São Paulo, Brasiliense, 1988).

23 Carlo Ginzburg. Signes, traces, pistes. Racines d'un paradigme de l'indice ». Le Débat, n. 6, novembre 1980. (Trad. bras. "Sinais: raízes de um paradigma indiciário". In : Mitos, emblemas, sinais: morfologia e história. 3ed. São Paulo: Companhia das Letras, 2009, p. 143-179).

24 Hans Belting. Pour une anthropologie des images. Paris, Gallimard, 2004. (obra ainda não traduzida no Brasil).
} 
Você deixou a França para trabalhar nos Estados Unidos durante quinze anos. Quais diferenças você encontrou entre USA e França do ponto de vista do trabalho acadêmico?

Quando eu cheguei nos Estados Unidos, percebi principalmente as vantagens inegáveis do sistema: a facilidade de empreender, uma espécie de flexibilidade, de fluidez institucional e também o aspecto salarial. É preciso dizer que dava a impressão, pela primeira vez, que eu podia ganhar normalmente a vida. Essa impressão durou certo tempo e, além do mais, eu estava de longa data mergulhado na literatura, no cinema e no jazz americanos... Em consequência disso, quando eu desembarquei na costa oeste, no início dos anos 80 , eu me sentia um pouco como no cinema, dentro da vida cotidiana, e quando compreendi que eu podia provavelmente me instalar e trabalhar lá, decidi tentar a aventura, sem hesitar, com muito entusiasmo. Eu vivi uma espécie de renascimento profissional. Você tem lá grandes bibliotecas, onde os livros estão em acesso direto, você pode pedir emprestado quantos você quiser. Nas bibliotecas, há pequenos gabinetes individuais, computadores por todos os lados, bem, o paraíso para os pesquisadores - como Pinocchio logo que ele desembarca na "Ilha das crianças perdidas"...

Depois, pouco a pouco, percebi os defeitos e a fragilidade do sistema, porque eles existem. Eu percebi muito conformismo. Há a impressão de que existem modas intelectuais que chegam, mobilizam as paixões acadêmicas durante um certo tempo e depois, como as grandes ondas do Pacífico, se vão. Eu atravessei assim o momento da desconstrução, dos estudos culturais, dos estudos de gênero e cheguei nos estudos "pós-coloniais". Eu estava verdadeiramente saturado e disse a mim mesmo que o pensamento merece mais do que ser submisso a regras do mercado e da moda, mesmo sendo elas acadêmicas.

Nunca gostei do modo como as carreiras se fabricam. Há uma relação entre produção acadêmica e progressão que era mais adequada, parecia-me, mais lá que aqui; mas, infelizmente, na França, há também uma relação bastante quantitativa na produção. E eu constatei bem a indiferença, ou o cinismo com respeito ao conteúdo e ao pensamento. Terminei por ter o sentimento de que o momento do retorno estava chegando, embora, depois, eu percebesse mais nitidamente que as razões pelas quais eu partira eram aquelas pelas quais eu voltara.

\section{Você partiu linguista e quando voltou à França encontrou um lugar na antropologia...}

$\mathrm{Eu}$ fazia antropologia histórica e história cultural, mas não tenho formação de antropólogo, nem de historiador. Eu me fiz sozinho, pelo interesse por certas questões, seguindo o fio de minhas curiosidades, o que não é sempre confortável, porque quando se trata de ser promovido, ou de encontrar um cargo, acabamos sempre caindo em considerações disciplinares. De qualquer modo, eu tentei, como lhe disse, encontrar lugares onde eu pudesse respirar. Quando estava na América, eu podia respirar, quando fiz AD com Pêcheux, eu podia, na História do corpo, igualmente.

Simplificando um pouco, poder-se-ia dizer que, no nosso ofício, há pessoas que seguem a linha do seu pensamento, de suas curiosidades, de suas obsessões, às vezes. E há aquelas que seguem o modelo das disciplinas, dos métodos e dos problemas colocados a elas; não é o mesmo gênero de indivíduos, nem de carreiras. Quanto a mim, as pessoas com quem eu tenho cumplicidade são frequentemente aquelas que estão do lado dos objetos e das curiosidades. E é isso que tento seguir. Mas eu queria acrescentar, para terminar esse ponto, uma coisa que aqueles da minha geração parecem não reconhecer suficientemente: é que eu tive, nós tivemos, muita sorte e muita liberdade, para aqueles dentre nós que 
julgaram bom tê-la. Os jovens pesquisadores são hoje submetidos, no domínio das humanidades, a limitações e a pressões bem mais fortes que aquelas às quais nós tínhamos conhecido. Esta é uma coisa que não devemos esquecer, na comunidade universitária em geral, onde as questões de transmissão têm tanta importância: a necessária solidariedade entre as gerações. E a necessidade de transmitir uma liberdade essencial: aquela do espírito.

\section{Quais são suas curiosidades e suas perspectivas de trabalho hoje?}

Há três coisas essenciais que eu faço neste momento.

(i) $\mathrm{Eu}$ sou frequentemente interpelado, notadamente por estudantes e colegas brasileiros da $\mathrm{AD}$, e eu thes respondo, porque isso me obriga a voltar sobre o que eu fiz, a refletir sobre meus laços com Pêcheux, com o trabalho de Foucault, sobre o discurso e sua análise e a responder questões antigas, a colocá-las diferentemente, como eu fiz com você nesta entrevista. Eu estou convencido de que as formas de dominação produzidas no funcionamento das mídias de comunicação política, que não correspondem à maneira pela qual se refletia quando se fazia $\mathrm{AD}$, merecem uma atenção e novas formas de análise. É dentro desse quadro que eu reflito sobre a relação entre imagem e discurso, questão que me parece hoje incontornável.

(ii) Há um outro projeto que concerne a um livro escrito por mim provisoriamente e que traz pesquisas que eu tinha feito há um bom tempo, em companhia notadamente de Michel de Certeau, sobre a relação entre inconsciente e linguagem, sobre a maneira pela qual se descobriram as manifestações do inconsciente na linguagem no século XIX. Contrariamente ao que se pensa frequentemente, os psiquiatras do século XIX estavam perfeitamente a par do fato de que "o inconsciente é estruturado como uma linguagem" - se é preciso continuar a falar assim - e eles trabalhavam já essas questões. Nesse livro, eu tento mostrar como, pouco a pouco, veem-se as primeiras formas de personalidade dividida aparecer nas manifestações linguísticas, através essencialmente das alucinações verbais, das pessoas que ouvem vozes e através das línguas que as pessoas criam. Eu me interessei pelos médiuns que, no final do século XIX, inventavam línguas. Uma delas era Hélène Smith, que inventou seis ou sete línguas. Ela era assistida por um séquito de cientistas que se debruçavam sobre sua cabeceira, entre os quais Saussure e também o fundador da psicologia experimental em Genebra, Théodore Flournoy, sobre o qual se pensa ter tido a intuição do inconsciente antes de Freud. Mas esse trabalho não está ainda concluído, eu o levo comigo, e com ele o sentimento de que falta um ou dois pedaços do quebra-cabeça, os quais eu digo a mim mesmo que terminarei por encontrá-los...

(iii) Depois, finalmente, com Corbin e Vigarello, nós estamos concebendo uma História da virilidade da Antiguidade aos nossos dias, para as edições do Seuil. Eu estou encarregado do século XX e, assim, de fazer valer o fato de que a dominação masculina não cessou, mas se transformou. A identificação secular do poder viril com o pênis masculino está em vias de desaparecer e, assim, a virilidade se torna um significante que se põe a flutuar. Eu não estou subestimando os efeitos da dominação masculina, mas eu contesto as mudanças. Eu devo, além da direção do volume III e da co-direção da obra, abordar nele duas questões.

De um lado, eu vou observar as formas do discurso público e farei uma história dos discursos mostrando os efeitos de sua "feminilização" progressiva. O orador à la Jaurès ${ }^{25}$, no começo do século, podia falar sem microfone a multidões incontáveis, e todo mundo o entendia, porque havia na voz "de macho" do tribuno popular um poder que se perdeu

\footnotetext{
25 Jean Léon Jaurès (1859 - 1914): Político socialista francês, cujo discurso propunha uma revolução social democrática e não
} violenta. 
desde então. Eu vou examinar essa teatralidade para mostrar como, sob o efeito ao mesmo tempo de transformações tecnológicas e de mutações sociais e históricas no sentido democrático, vê-se o discurso público se transformar e se feminilizar. Eu queria, finalmente, voltar-me a todas essas estranhas questões que se colocam em torno das aparições públicas de mulheres como Hillary Clinton: as dificuldades que elas encontram, os julgamentos que se fazem delas. Eu observarei também as encenações sarkosianas, com seus simulacros viris e "suas trapaças sensíveis".

Em segundo lugar, eu vou fazer a história da exibição viril dos músculos ao longo do século e tentar mostrar como essas hipérboles musculares dos bodybuilders ${ }^{26}$, dos quais já me ocupei outrora ${ }^{27}$, são sintomas de fraqueza e de inquietude viris e representam, desse modo, um signo de perda de poder masculino. É o paradoxo da sala de ginástica: mais $o$ poder masculino está em perigo, mais os músculos inflam.

O que eu tentarei mostrar, finalmente, é também que essa história da virilidade diz respeito a todo mundo, e não somente aos homens. Isso concerne às relações entre as mulheres e os homens. O que a virilidade faz às mulheres? É também essa a questão, e não apenas quando elas sofrem seus efeitos, mas também quando elas a tomam por modelo.

17 de junho de 2008. 